\begin{tabular}{|l|l|l||}
\hline \multicolumn{2}{|c|}{ PublisherInfo } \\
\hline \hline PublisherName & $:$ & BioMed Central \\
\hline \hline PublisherLocation & $:$ & London \\
\hline \hline PublisherImprintName & $:$ & BioMed Central \\
\hline \hline
\end{tabular}

\title{
Schizophrenia surprise
}

\begin{tabular}{|l|l|l||}
\hline \multicolumn{2}{|c|}{ ArticleInfo } \\
\hline \hline ArticleID & $:$ & 4462 \\
\hline \hline ArticleDOI & $:$ & $10.1186 /$ gb-spotlight-20020426-01 \\
\hline \hline ArticleCitationID & $:$ & spotlight-20020426-01 \\
\hline \hline ArticleSequenceNumber & $:$ & 128 \\
\hline \hline ArticleCategory & $:$ & Research news \\
\hline ArticleFirstPage & $:$ & 1 \\
\hline \hline ArticleLastPage & $:$ & 2 \\
\hline \hline & & RegistrationDate : 2002-4-26 \\
\hline ArticleHistory & $:$ & OnlineDate \\
\hline \hline ArticleCopyright & $:$ & BioMed Central Ltd2002-4-26 \\
\hline \hline ArticleGrants & $:$ & \\
\hline \hline ArticleContext & $:$ & 130593311 \\
\hline \hline
\end{tabular}




\section{Jonathan B Weitzman}

Email: jonathanweitzman@hotmail.com

There is some evidence that schizophrenia may have a genetic contribution, and susceptibility loci have been reported on chromosome 1q. In the April 26 Science Levinson et al. report their failure to confirm this genetic linkage in a larger sample (Science 2002, 296:739-741). They genotyped 16 microsatellite markers in 779 informative pedigrees containing almost a thousand affected sibling pairs, and an additional 1918 schizophrenic individuals. Statistical analysis of this large multicenter sample failed to provide support for linkage between the disease and loci on chromosome 1q. Levinson et al. conclude that if there are any susceptibility genes present on chromosome 1q they must have a small population-wide genetic effect.

\section{References}

1. Searching for schizophrenia genes.

2. Location of a major susceptibility locus for familial schizophrenia on chromosome 1q21-q22.

3. Science, [http://www.sciencemag.org] 